\title{
Physicochemical properties and fatty acid composition of crude and processed Adenopus breviflorus Benth seed oil
}

\author{
J. O. Alademeyin and J. O. Arawande*
}

Department of Science Laboratory Technology, Rufus Giwa Polytechnic, Owo, Ondo state, Nigeria

\begin{abstract}
Crude oil was extracted from Adenopus breviflorus benth seeds using n-hexane and the extracted oil was degummed, neutralized and bleached. Oil sample at each stage was assessed for physicochemical parameters and fatty acid composition. The oil yield was $54.35 \pm$ $0.120 \%$. The specific gravity (at $25^{\circ} \mathrm{C}$ ) of the oil was $0.901 \pm 0.001$ and the refractive index $\left(\right.$ at $25^{\circ} \mathrm{C}$ ) was $1.472 \pm 0.012$. Processing of the crude oil resulted in progressive decrease in turbidity, colour, free fatty acid, acid value, peroxide value and saponification value. There was increase in smoke point $\left(202.00 \pm 0.10\right.$ to $\left.239.00 \pm 0.30^{\circ} \mathrm{C}\right)$, flash point $\left(305.00 \pm 0.78\right.$ to $\left.322.00 \pm 1.05^{\circ} \mathrm{C}\right)$ and fire point ( $352.00 \pm 1.00$ to $\left.359.00 \pm 1.25^{\circ} \mathrm{C}\right)$ as well as iodine value (112.50 to 120.20$)$ and total fatty acid during the processing of the oil. The fatty acids detected in the oil samples were lauric myristic, palmitic, stearic, oleic, linoleic and linolenic acids. The predominant fatty acid was linoleic acid (57.597 $-59.774 \%)$ followed by oleic acid $(11.099-12.766 \%)$ while the least fatty acid was lauric acid $(0.053-0.355 \%)$.
\end{abstract}

Keywords: Adenopus breviflorus benth seed oil; Extraction; Degumming; Bleaching; Physicochemical properties; Fatty acid composistion

\section{Introduction}

Fats and oils whether the source is animal, vegetable or marine in origin represent the highest source of energy. Apart from being a source of reserved energy, fat deposits insulate the body against loss of heat and protect vital organs against mechanical injury. They are important food source for man and extensively used for nutritional, cosmetic and industrial purposes as well. They are also used for producing drug dispersants in therapeutics (Rauken and Kill, 1993). Fats and oils solubilise vitamins A, D, E and K which are necessary for the maintenance of health and they are source of essential fatty acids thus contributing to several metabolic functions (Lawson, 1995; Abitogun and Oshodi, 2010).

Fats and oils, chemically, are mixture of fatty acid esters of the trihydroxy alcohols, glycerols (Jacobs, 1999) and the esters are called trimesters or triglycerides (Reward, 1997). The main distinction between oils and fats is that oils are liquid while fats are solid at room temperature (John, 1990). Fats and oils obtained from various sources differ from one another in their physical and chemical properties because they contain varying amount of different mixed esters. Some of these esters are solid, some liquids, some volatile, some saturated and some unsaturated compounds. Therefore, each ester influences the physical and chemical properties of an oil or fat in some measure according to the amount of that ester in the fat or oil. These differences are the basis of tests for their identification (Jacobs, 1999). The chemical composition of oil extract consequently gives a qualitative identification of oil, and is a very important area in the selective application guide in the commercialization and utility of oil products (Salunkhe et al., 1992).

Although the characteristics of oils from different sources depend mainly on their compositions and no oil from a single source can be suitable for all purposes (Mohammed and Thomas, 2003). Oils and fats occur in oil seeds (18-70\%), fruit pulp (30-58\%), animal tissues (60-90\%) and fish (1020\%) (Gunstone and Norris, 1983). The method for removing the oil is largely dependent upon the source (Gunstone and Norris, 1983). A number of seed oils have been characterized for the identification of several fatty acids of nutritional and neutraceutical importance but the vast majority have not been adequately evaluated.

Adenopus breviflorus benth belong to the family cucurbitacae. The family is a diverse family of plants in the temperate

*Corresponding author. e-mail: joawande1@yahoo.com 
zones but also thrives in hot and arid regions of the world (Weihrauch and Teter, 1994; Umerie et al., 2009). The family is also moderately large consisting of about 110 genera and 640 species (Evans, 2002) and is represented in Nigeria by 21 genera, many of which are of considerable economic importance. Some genera are significant as oil plants, medicinal plants, sources of tanning materials, sponges and household utensils (Okoli, 1984; Umerie et al., 2009; Giwa et al., 2010). Other genera such as Telfairia, Cucurbita and Citrullus are economically cultivated in Southern Nigeria since their fruits and/or leaves constitute important items in the local diet (Umerie et al., 2009). Some members of cucurbitaceae family are grown for their carbohydrate rich fruits, which contain many oil and protein rich seeds that are discarded as waste during the processing of the fruit. A few examples include water melon (Citrulus vulgaris), muskmelon (Cucumis melo), Pumpkin (Cucurbita pepo), Sponge gourd (Luffa cylindrical), (Weihrauch and Teter, 1994; Umerie et al., 2009). Oil from the seeds of Cucurbits that is traditionally used as human foods is considered safe for human consumption. Plant oils represent one of the important key materials that can be obtained from biomass cheaply and processed readily to supply the appropriate and important raw materials for the chemical and allied industries (Akintayo, 2009).

Adenopus breviflorus benth grows wild and is particularly abundant in Southern Nigeria (Oshodi, 1996 and Umerie et al., 2009). It is called 'Egwoli' in Edo language and 'Eso gbegbe' by Yoruba race both in Nigeria (Oshodi, 1996). It is a tendril climber and would usually lie on the ground for want of something to climb and climbs over shrubs and herbs by means of axillary tendrils. (Akintayo and Bayer, 2002). The leaves are simple, alternate and palmately veined (Dutta, 1995; Umerie et al., 2009). The fruit is a pepo and appear green with cream-coloured narrow blotches measured $1-5 \mathrm{~cm}$ in length. The pulp is bitter due to the presence of tetracyclic triterpenoids (Kar, 2007). The fruit is used in folkoric medicine as an abortifacient (Elujoba et al., 2009).

The seeds number up to 400 in an average-size fruit and contain fixed oil (Umerie et al., 2009). The seeds are covered with a thin hull which when dried can easily be removed by hand (Akintayo and Bayer, 2002). The seeds are mostly utilized as a soup ingredient in the mid-western part of Nigeria.
Oshodi (1992) has reported the proximate composition, nutritionally valuable minerals and functional properties of the seed flour and protein concentrates. Oshodi (1996) also reported the amino and fatty acids composition of the Adenopus breviflorus benth seeds.

There are many studies on the proximate composition and nutritive value of seeds of Adenopus breviflorus benth (Akintayo and Bayer, 2002), scanty information is available on the physicochemical properties of the seed oil and fatty acid profile (Oshodi, 1996), but little or no information is available on physicochemical properties and fatty acid composition of the processed seed oil. Therefore, this work is aimed at assessing the physicochemical properties and fatty acid composition of crude, degummed, neutralized and bleached Adenopus breviflorus benth seed oil with a view of establishing the effects of these processes on the parameters.

\section{Materials and methods}

\section{Collection and preparation of samples}

Adenopus breviflorus benth seeds were obtained in the dried form from a local market at Ekpoma in Edo state of Nigeria. The seeds were screened to remove damaged seeds and unwanted materials. They were mixed thoroughly and samples for dry-milling were taken by the quartering method. The samples were then de-shelled and smoothly milled into powdery form. The flour was then stored in an air tight container for further analysis (oil extraction).

\section{Oil extraction}

The powdered Adenopus breviflorus benth seeds were then subjected to soxhlet extraction using hexane as solvent. $50 \mathrm{~g}$ of ground seeds were placed into a cellulose paper cone and extracted using hexane (B.P $65^{\circ} \mathrm{C}$ ) in a soxhlet extractor for 8 hours. The oil was then recovered by simple distillation and residual solvent was removed by drying in a hot-air oven at $45{ }^{\circ} \mathrm{C}$ for 2 hours (Erickson et al., 1980; Bligh and Dyer, 2009). The residual oil was termed crude Adenopus breviflorus benth seed oil. The samples were extracted in sets until enough oil required for the analysis was obtained and stored in an air-tight bottle for further analysis. 
Refining process

The crude oil extracted from Adenopus breviflorus benth seeds was then subjected to degumming, neutralization and bleaching processes.

\section{Degumming process}

$400 \mathrm{~cm}^{3}$ of the crude oil was heated to temperature of $70{ }^{\circ} \mathrm{C}$ followed by addition of $0.80 \mathrm{~cm}^{3}$ of $50 \%$ phosphoric acid and the mixture was then vigorously stirred for 10 minutes. Thereafter $10 \mathrm{~cm}^{3}$ of water heated to $80{ }^{\circ} \mathrm{C}$ was added and whole mixture agitated for another 10 minutes. The agitation was stopped and the mixture was allowed to stand undisturbed for 1 hour. The mixture was then separated into two layers i.e. oil and gum. The gum was drained off while the oil obtained was termed as degummed oil (Erickson et al., 1980; Salunkhe et al.,1992). The degummed oil was further subjected to alkali neutralisation.

\section{Neutralization process}

$200 \mathrm{~cm}^{3}$ of the degummed oil sample was heated to temperature of $70{ }^{\circ} \mathrm{C}$ with constant stirring in a beaker. $3.3 \mathrm{~cm}^{3}$ of 3.59 M (20 Baume) sodium hydroxide solution was added to the oil with vigorous stirring and the temperature rose to 90 ${ }^{\circ} \mathrm{C}$. Thereafter, $10 \mathrm{~cm}^{3}$ of saturated solution of sodium chloride (an electrolyte) was added and the resulting mixture was stirred vigorously at $90{ }^{\circ} \mathrm{C}$ for 30 minutes. The mixture was left undisturbed in a separating funnel for 6 hours and it was later separated into two layers, the lower layer (soap stock) was then heated to $90{ }^{\circ} \mathrm{C}$ and washed with water heated to $95{ }^{\circ} \mathrm{C}$. The washing was done six consecutive times to remove any excess caustic soda and water soluble gum remaining in the oil (Erickson et al., 1980; Salunkhe et al., 1992). The resulting neutral oil was then dried in a hot air oven, and later cooled in a desiccator. The dried oil was further bleached.

\section{Bleaching processe}

$100 \mathrm{~cm}^{3}$ neutralized oil was heated to $75{ }^{\circ} \mathrm{C}$ with constant agitation. Then $1.00 \mathrm{~g}$ of the bleaching earth was added and the mixture was heated to $110{ }^{\circ} \mathrm{C}$ with constant stirring for 45 minutes (Erickson et al., 1980; Salunkhe et al.,1992). The mixture was then filtered and the resulting oil termed bleached oil.
Physicochemical characterization of the oil samples.

The crude, degummed, neutralized and bleached oils were analysed for physicochemical properties. The moisture content and specific gravity were determined according to AOAC, 1999 while the refractive index was measured using Abbey Refractometer coupled with thermometer (ASTM, 1985). The colour was determined using Lovibond Tintometer (Model 520). The colour of crude oil was determined in half $1 / 2$ inch cell while that of degummed, neutralized and bleached oils were determined in 1 inch cell. The colour was calculated based on the expression $(5 R+Y)-B$, where R stands for red pigment, $\mathrm{Y}$ for yellow pigment and $\mathrm{B}$ for blue pigment (Bernadini, 1973; Abitogun and Oshodi, 2010). The flash and fire points were measured using GallenKamp Automatic Pensky-Martens flash point and fire point tester with thermometer while the smoke point was determined using Cleveland Open Cup apparatus (ASTM, 1985; Lawson, 1995). The temperature at which turbidity is first detectable was also measured using Palm Test turbidity tube (ASTM, 1985). The free fatty acid, acid value, saponification value, peroxide value were determined using methods described by AOAC, 1999 while iodine value was determined by method described by (Pearson, 1976; Jacobs, 1999).

\section{Fatty acids identification}

The oil samples were converted to Fatty acid methyl esters (FAMEs) using the method described by Oshodi, 1996 and Hall, 1982. The fatty acid methyl esters were analyzed using an HP 6890 gas chromatograph fitted with flame ionization detector and powered with HP chemstation Rev.09.01 [206] software. The career gas was helium at pressure of 19 psi. The FAMEs sample $(1.5 \mu \mathrm{L})$ was injected and the separation was carried out on an HP capillary column (HP-INNowax; cross-linked PEG); $30.0 \mathrm{~m}$ length, $0.32 \mathrm{~mm}$ i.d., and $0.50 \mu \mathrm{m}$ film thickness. The oven temperature was held initially at $60^{\circ} \mathrm{C}$ for 2 minutes, increased from $180^{\circ} \mathrm{C}$ at $12^{\circ} \mathrm{C} / \mathrm{min}$ to $320^{\circ} \mathrm{C}$ at $14^{\circ} \mathrm{C} / \mathrm{min}$ and then maintained at $320^{\circ} \mathrm{C}$ for 5.0 minutes. The temperature of the injection port and the detector were set at $250^{\circ} \mathrm{C}$ and $300^{\circ} \mathrm{C}$ respectively. The peaks were identified by comparison with standard fatty acid methyl esters (ASTM, 1985). 


\section{Results and discussion}

The physicochemical properties of crude, degummed, neutralized and bleached oils obtained from Adenopus breviflorus benth seeds are shown in Table I. Adenopus breviflorus benth seeds contained $54.35 \pm 0.12 \%$ crude oil and the oil was light yellow with colour unit of 13.5 in half inch cell. The high oil yield value indicated that the seeds were rich in oil hence the processing of the oil for industrial or edible purpose would be economical. The oil yield is a little bit lesser than 56.22\% reported by Akintayo and Bayer (2002). There was no moisture in the crude oil sample analysed and this implied that the oil may have prolong shelf life. The colour of degummed, neutralised and bleached oil samples were 9.0, 6.0 and 3.5 lovibond unit respectively in one inch cell. The progressive decrease in colour from crude oil to bleached oil was as a result of phosphoric acid used for degumming and bleaching earth specifically used to remove colour pigments during bleaching (Bernadini, 1973; Gibb et al., 2004; Abitogun and Oshodi, 2010). There was no remarkable difference in the values of both specific gravity $(0.9000-0.9001)$ and refractive index $(1.471-1.472)$ of crude, degummed, neutralised and bleached oil samples. The specific gravities of the oil sample were almost the same with 0.9005 reported by Akintayo and Bayer, 2002 for crude Adenopus breviflorus benth seed oil but lower than the specific gravity (0.913) of pumpkin seed kernel oil reported by Mohammed, 2004. The refractive indices of the oil samples were in conformity with 1.4721 reported for Adenopus benth seed oil (Akintayo and Bayer, 2002). The smoke point $\left({ }^{\circ} \mathrm{C}\right)$ for crude, degummed, neutralised and bleached oils were $202.00 \pm 0.10,208.00 \pm 0.08,213.00 \pm 0.20$ and $239.00 \pm 0.30$ respectively while that of flash point $\left({ }^{\circ} \mathrm{C}\right)$ were $305.00 \pm 0.78$, $310.00 \pm 1.20,316.00 \pm 1.08$ and $322.00 \pm 1.05$ and that of fire points $\left({ }^{\circ} \mathrm{C}\right)$ were $352.00 \pm 1.00,354.00 \pm 1.20,356.00 \pm 0.20$ and $359.00 \pm 1.25$ respectively. The progressive increase in

Table I. Physicochemical properties of crude, degummed, neutralized and bleached oils obtained from Adenopus breviflorus benth seeds

\begin{tabular}{|c|c|c|c|c|}
\hline Parameters & Crude oil & Degummed oil & Neutralized oil & Bleached oil \\
\hline $\begin{array}{l}\text { Specific gravity } \\
\left(\text { at } 25^{\circ} \mathrm{C}\right)\end{array}$ & $0.9000 \pm 0.0002$ & $0.9001 \pm 0.0001$ & $0.9001 \pm 0.0001$ & $0.9000 \pm 0.002$ \\
\hline $\begin{array}{l}\text { Refractive Index } \\
\left(\text { at } 25^{\circ} \mathrm{C}\right)\end{array}$ & $1.472 \pm 0.015$ & $1.471 \pm 0.013$ & $1.472 \pm 0.011$ & $1.472 \pm 0.012$ \\
\hline $\begin{array}{l}\text { Moisture } \\
\text { Content (\%) }\end{array}$ & $0.00 \pm 0.00$ & $0.00 \pm 0.00$ & $0.00 \pm 0.00$ & $0.00 \pm 0.00$ \\
\hline $\begin{array}{l}\text { Turbidity } \\
\text { Point (JTU) }\end{array}$ & $7.00 \pm 0.20$ & $5.00 \pm 0.15$ & $4.00 \pm 0.12$ & $4.00 \pm 0.10$ \\
\hline Smoke point $\left({ }^{\circ} \mathrm{C}\right)$ & $202.00 \pm 0.10$ & $208.00 \pm 0.08$ & $213.00 \pm 0.20$ & $239.00 \pm 0.30$ \\
\hline Flash point $\left({ }^{\circ} \mathrm{C}\right)$ & $305.00 \pm 0.78$ & $310.00 \pm 1.20$ & $316.00 \pm 1.08$ & $322.00 \pm 1.05$ \\
\hline Fire point $\quad\left({ }^{\circ} \mathrm{C}\right)$ & $352.00 \pm 1.00$ & $354.00 \pm 1.20$ & $356.00 \pm 0.20$ & $359.00 \pm 1.25$ \\
\hline $\begin{array}{l}\text { Colour } \\
(5 \mathrm{R}+\mathrm{Y}-\mathrm{B})\end{array}$ & 13.5 & 9.0 & 6.0 & 3.5 \\
\hline $\begin{array}{l}\text { Free Fatty Acid } \\
(\% \text { Oleic-acid })\end{array}$ & $1.88 \pm 0.09$ & $0.98 \pm 0.01$ & $0.62 \pm 0.02$ & $0.75 \pm 0.01$ \\
\hline $\begin{array}{l}\text { Acid value } \\
(\mathrm{mgKOH} / \mathrm{g})\end{array}$ & $3.74 \pm 0.19$ & $1.95 \pm 0.15$ & $1.22 \pm 0.06$ & $1.48 \pm 0.01$ \\
\hline Iodine value & $112.50 \pm 0.24$ & $115.00 \pm 0.18$ & $116.80 \pm 0.10$ & $120.20 \pm 0.40$ \\
\hline $\begin{array}{l}\text { Peroxide value } \\
\text { (meq peroxide/Kg) }\end{array}$ & $1.88 \pm 0.04$ & $1.12 \pm 0.02$ & $0.84 \pm 0.05$ & $0.50 \pm 0.03$ \\
\hline $\begin{array}{l}\text { Saponification } \\
\text { value }(\mathrm{mgKOH} / \mathrm{g} \text { oil })\end{array}$ & $186.60 \pm 0.82$ & $182.90 \pm 0.09$ & $176.20 \pm 0.92$ & $174.60 \pm 0.98$ \\
\hline Yield (\%) & $54.35 \pm 0.12$ & & & \\
\hline
\end{tabular}

Mean \pm standard deviation of triplicate determination, $\mathrm{R}=$ Red, $\mathrm{Y}=$ Yellow, $\mathrm{B}=$ Blue 
values of smoke, flash and fire points from crude oil to bleached oil might be as a result of removal of impurities such as volatile organic material and the residual extraction solvent during the oil processing (Erickson et al., 1980; Nielsen, 2002; Abitogun and Oshodi, 2010). The high smoke, flash and fire points of the oil suggest that it can be suitable for deep frying purpose (Akintayo and Bayer, 2002; Bello et al., 2011). The smoke point of the crude oil $\left(202 \pm 0.10^{\circ} \mathrm{C}\right)$ is lower than $213.5^{\circ} \mathrm{C}$ reported for crude groundnut oil (FAO/WHO, 1993; Bello et al., 2011) and $245.00 \pm 1.75^{\circ} \mathrm{C}$ reported for Telfairia occidentalis seed oil (Bello et al., 2011). It is noted that the oil samples containing low free fatty acid give high smoke, flash and fire point (FAO/WHO,1993) and this enhances the suitability of the oil for deep frying purpose (Akintayo and Bayer, 2002; Bello et al., 2011).

Free fatty acid (FFA) and acid values are among the characteristics that are necessary for the confirmation of the identity and edibility of oil. FFA can stimulate hydrolytic deterioration of oils to form off- flavour components. The free fatty acid (\% oleic acid) for the crude, degummed, neutralised and bleached oils are $1.88 \pm 0.09,0.98 \pm 0.01,0.62 \pm 0.02$ and $0.75 \pm 0.01$ respectively while their respective acid values $(\mathrm{mgKOH} / \mathrm{g})$ are $3.74 \pm 0.19,1.95 \pm 0.15,1.22 \pm 0.06$ and $1.48 \pm 0.01$. These values are relatively low and this suggests the utilization of the oil as good edible oil (Akintayo and Bayer, 2002). The FFA and acid value decreased from crude oil to neutralised oil but sudden increase was observed in bleached oil. The decrease in FFA and acid value is owing to the effective use of caustic alkali in neutralization of the oil sample which led to reduction in the free fatty acids, acid values and other impurities while the increase in FFA and acid values of bleached oil is as a result of acidic nature of bleaching earth used for colour removal (Bernadini, 1973; Ihekoronye and Ngoddy, 1985; Salunkhe et al., 1992). The acid values of the samples were lower than the minimum acceptable value of $4.0 \%$ (for crude oil) recommended by the Codex Alimentarius Commission for oil seed (Abayeh et al., 1998). The peroxide values $\left(\mathrm{meqO}_{2} / \mathrm{Kg}\right)$ of crude, degummed, neutralized and bleached oil are $1.88 \pm 0.04$, $1.12 \pm 0.02,0.84 \pm 0.05$ and $0.50 \pm 0.03$ respectively. The low value was an indication that the oil has a high resistance to peroxidation and low rate of spoilage (Abayeh et al., 1998). This value is low compare to the maximum acceptable value of $10 \mathrm{meqO}_{2} / \mathrm{g}$ set by the Codex Alimentarius Commission for edible oils (Kilogour, 1986; Abayeh et al., 1998). The oil is thus stable and will not easily go rancid. The iodine values of the crude, degummed, neutralised and bleached oils are $112.50 \pm 0.24,115.00 \pm 0.18,116.80 \pm 0.10$ and $120.20 \pm 0.40$ respectively. The iodine value of the oil samples classified the oil among the semi drying oil (Fernando and Akujobi, 1987; Jacobs, 1999). In addition, the high iodine value of the oils indicates that the oil contains more unsaturated fatty acid than saturated fatty acid since iodine value is a measure of the extent of unsaturation of fatty acid present in fats and oils (Nielsen, 2002). The iodine values are comparable to iodine value of 112.10 for Adenopus benth seed oil (Das et al., 2002) and 121.03 for Africa pear, Caryodes edulis (Ajiwe et al., 1997). On the other hand, the values obtained are higher than 83.50 reported as iodine value of Moringa oleifera seed oil (Ogbunugafor, 2011). Moreover, the iodine value of the oil increases progressively at each stage of the processing owing to gradual removal of some impurities present. The saponification values $(\mathrm{mgKOH} / \mathrm{g}$ oil) of the crude, degummed, neutralised and bleached oil samples are $186.60 \pm 0.82,182.90 \pm 0.09,176.60 \pm 0.92$ and $174.60 \pm 0.98$ respectively. The saponification values are relatively low compare to palm kernel oil $(253.781 \mathrm{mgKOH} / \mathrm{g}$ ) (Arawande, 2013) and this is an indication that the oil will be better for edibility than industrial application for soap making.

Table II depicts the fatty acid composition of crude, degummed, neutralised and bleached oils obtained from Adenopus breviflorus benth seeds. The fatty acids detected in the crude, degummed, neutralized and bleached oil samples are lauric, myristic, palmitic, stearic, oleic, linoleic and linolenic acids. The amount (\%) of individual fatty acids in the crude oil are lauric acid 0.053, myristic acid 0.280, palmitic acid 9.617, stearic acid 9.452, oleic acid 11.099, linoleic acid is 57.597 and linolenic acid 0.500. Also, the values $(\%)$ of these fatty acids in degummed oil are lauric acid (0.239), myristic acid (0.900), palmitic acid (10.212), stearic acid (10.449), oleic acid (11.552), linoleic acid (58.306) and linolenic acid (1.341) respectively. In addition, the following fatty acids are present in the neutralized oil sample lauric acid $(0.286 \%)$, myristic acid $(0.980 \%)$, palmitic acid (10.760\%), stearic acid (10.540\%), oleic acid (12.120\%), linoleic acid (59.347\%) and linolenic acid (1.408\%). Moreover the amount (\%) of individual fatty acids present in 
Table II. Fatty acid composition of crude, degummed, neutralized and bleached oils obtained from Adenopus breviflorus benth seeds

\begin{tabular}{lclcc}
\hline Parameter & $\begin{array}{c}\text { Crude } \\
\text { oil (\%) }\end{array}$ & $\begin{array}{l}\text { Degummed } \\
\text { oil (\%) }\end{array}$ & $\begin{array}{c}\text { Neutralized } \\
\text { oil (\%) }\end{array}$ & $\begin{array}{c}\text { Bleached } \\
\text { oil(\%) }\end{array}$ \\
\hline Total Fatty Acid & 88.598 & 92.999 & 95.441 & 98.216 \\
Saturated Fatty Acid & 19.402 & 21.800 & 22.566 & 23.594 \\
Lauric Acid (C 12:0) & 0.053 & 0.239 & 0.286 & 0.355 \\
Myristic Acid (C 14:0) & 0.280 & 0.900 & 0.980 & 1.031 \\
Palmitic Acid (C 16:0) & 9.617 & 10.212 & 10.760 & 11.553 \\
Stearic Acid (C 18:0) & 9.452 & 10.449 & 10.540 & 10.655 \\
Monosaturated Fatty Acid & 11.099 & 11.552 & 12.120 & 12.766 \\
Oleic Acid (C 18:1) & 11.099 & 11.552 & 12.120 & 12.766 \\
Polysaturated Fatty Acid & 58.097 & 59.647 & 60.755 & 61.856 \\
Linoleic Acid (C 18:2) & 57.597 & 58.306 & 59.347 & 59.774 \\
Linolenic Acid (C 18:3) & 0.500 & 1.341 & 1.408 & 2.082 \\
\hline
\end{tabular}

the bleached oil are lauric acid 0.355 , myristic acid 1.031 , palmitic acid 11.553, stearic acid 10.655, oleic acid 12.766 , linoleic acid 59.774 and linolenic acid 2.082. In all the oil samples, linoleic acid has the highest value and next to it is oleic acid. It is observed that fatty acid value increased as the processing progressed from one stage to another. Also the high level of unsaturated fatty acid content of the oil in conjunction with its low free fatty acid and acid values confirm the reasons for its edibility (Messink and Katan, 1992; Akintayo and Bayer, 2002; Abitogun and Oshodi, 2010). Owing to the high content of unsaturated fatty acids in the oil, it may reduce the incident of heart attack (arteriosclerosis) which might occur as a result of excess cholesterol when consumed ( Keys et al.,1977; Garrow et al., 2004). The values $(\%)$ for saturated fatty acid in crude, degummed, neutralised and bleached oils are 19.402, 21.800, 22.566 and 23.594 respectively while that of monounsaturated fatty acids are $11.099,11.552,12.120$ and 12.766 accordingly and that of polyunsaturated fatty acids are 58.097, 59.647, 60.755 and 61.856 respectively. The total fatty acid (\%) in crude, degummed, neutralised and bleached oils are 88.598, $92.999,95.441$ and 98.216 respectively. There is progressive increase in the saturated, monounsaturated, polyunsaturated and total fatty acid of Adenopus breviflorus benth seeds oil during processing from crude oil to bleached oil. In all the oil samples, the percentage composition of polyunsaturated fatty acids was highest, followed by saturated fatty acid while that of monounsaturated fatty acid was the least.

\section{Conclusion}

Processing of Adenopus breviflorus benth seeds oil from crude to bleached oil increases iodine value, smoke point, flash point, fire point, saturated, monounsaturated, polyunsaturated and total fatty acid composition of the oil. Whereas processing of the oil from crude oil to bleached oil resulted in decrease in values of saponification, peroxide, colour and turbidity. It is obvious that if the bleached oil is deodourized, it will supply essential fatty acid needed in the body and the final refined oil will be of high quality in terms of physicochemical properties and this will enhance its edibility. It is further suggested that the bleached oil should be deodourised and the deodourised oil should be analysed for physicochemical properties and fatty acid composition.

\section{References}

Abayeh OJ, Aina EA and Okonghae CO (1998), Oil content and oil quality characteristics of some Nigerian oil seeds. J. Pure Appl. Sci. 1(1): 17-23.

Abitogun AS and Oshodi AA (2010), Effects of degumming and bleaching on physicochemical properties of crude sunflower oil. J. Chem. Soc. Nig. 35(2): 57-61.

Ajiwe VIE, Okeke CA, Nnabuike B, Ogunleye GA and Elebo E (1997), Application of oils extracted from Star apple (Chysophyllum africanum), horse eye bean seeds (Mucuna sloanei) and African pear (Dacryodes edulis). Biores. Technol 59: 259-261. 
Akintayo ET (2009), Preparation of new chemical feed stock from Adenopus breviflorus Benth seed oil. http//www.goggle.com Date retrieved 16/01/2009.

Akintayo ET and Bayer E (2002), Characterization and some possible uses of Plukenetia conophora and Adenopus breviflorus seeds and seed oils. Boires. Technol. 85: 95-97.

AOAC (1999), Official method of Analysis of the Association of Official, Analytical Chemist. (Washington D.C. USA) 1999, pp. 1250-1255.

Arawande JO (2013), Antioxidative activities of extract of fruit peels and vegetables on edible oils. Ph.D. Thesis, (Federal University of Technology, Akure, Ondo State. Nigeria) 2013, pp.61.

ASTM (1985) American Society for Testing Materials. (ASTM Publication) 1985, pp.31-36, 40-48.

Bello MO, Akindele TL, Adeoye DO and Oladimeji AO (2011), Physicochemical properties and fatty acid profile of seed oil of Telfairia occidentalis Hook, F. Int. J. Basic Appl. Sci. 11(6): 9-14.

Bernardini E (1973), Oil and Fat Technology, (Publishing House Technology, S. R.L.Rome) 1973, pp. 69-10, 709-719.

Bligh WJ and Dyer WJ (2009), A rapid method of total lipid extraction and purification. J. Biochem. Physiol. 37: 911-917.

Das M, Das SK and Suthar SH (2002), Composition of seed and characteristics of oil from Karingda Int. J.Food Sci. Technol. 37: 893-896.

Dutta AC (1995), Botany for Degree Students $6^{\text {th }}$ Ed. (Oxford University Press, Calcutta, India) 1995, pp. $85-93$.

Elujoba AA, Olagbende SO and Adesina SK (2009), Antiimplantation activity of the fruit of lagenaria breviflora Robert. http//www.goggle.com Date retrieved $16 / 01 / 2009$.

Erickson DR, Pryde EH, Brekks OL, Mount TL and Falb RA (1980), Handbook of Soy oil processing and utilization: American Soya Bean Association. (St.Louis and
American oil Chemists society, St. Lous Missouri and champaign Illinois) 1980, pp. 65- 68.

Evans WC (2002), Trease and Evans pharmacognosy. 15 $5^{\text {th }}$ Ed. (W.B. Saunders company limited, Edinburgh) 2002, pp. $55-68$.

FAO/WHO (1993), Composition and selected uses of fats and oils in food: In Report of the joint FAO/WHO Expert Consultation on Fats and Oils in Human Nutrition, Rome, pp.5 - 27.

Fernando CEC and Akujobi EO (1987), Chemical analysis of selected vegetable oils and fats of Sokoto State of Nigeria. J. Basic Appl. Sci. 1:11.

Garrow JS, James WPT and Ralph A (2004), Human Nutrition and Dietetics. (Churchill Livingstone. An imprint of Elsevier Limited, London.) 2004, pp.80 - 95.

Gibb DJ, Owens FN, Mir PS, Ivan MC and Allister TA (2004), Value of sunflower seed in finishing Diets of feedlot cattle. Journal of Animal Science 82: 2679.

Giwa S, Abdullah LC and Adam NM (2010), Egunsi (Citrullus colocynthis L.) seed oil as potential biodiesel feedstock. Energies 3: 607-618.

Gunstone FD and Norris FA (1983), Lipids in Foods Chemistry Biochemistry and Technology, (Pergamon press, New York) 1983, pp. 58 - 68.

Hall GM (1982), Silage from tropical Fishes: Lipid behavior. J. Food Technol. 21: 45-54.

Ihekoronye AI and Ngoddy PO (1985), Integrated Food Science and Technology for Tropics. (Macmillian publisher Limited, London) 1985, pp.58 - 71,194 - 2006.

John MD (1990), Principle of food Chemistry. $2^{\text {nd }}$ Ed. (Van Nostrand Reinhold, New York) 1990, pp. 57-70.

Jacobs MB (1999), The Chemical Analysis of Food and Food Product. $3^{\text {rd }}$ Ed. (CBS Publsher, New Dehli, India) 1999, pp. 357 - 390.

Kar A (2007), Pharmacognosy and Pharmacobiotechnology (revised-expanded second ed.) (New Age International (P) Limited publishers, New Delhi,India) 2007, pp. $102-113$. 
Keys A, Anderson JT and Grange F (1977), Prediction of serum cholesterol response of man to changes in fats in the diet. Lancet 2: 959 - 966.

Kilgour OFG (1986), Mastering Nutrition (Academic press, New York) 1986, pp.106 - 144

Lawson H (1995), Food oils and fats. (Chapman and Hall, New York) 1995, pp.65 - 69.

Messink RP and Katan KB (1992), Effect of dietary fatty acid on serum lipids and lipoproteins. Arterioscler Thromb 12: 911-912.

Mohammed AA (2004), Chemical composition and oil characteristics of Pumpkin (Cucurbita maxima) seed kernels. Food Sci. Agric. 129: 5-18.

Mohammed RF and Thomas JM (2003), Determination of lipid classes and fatty acid profile of Niger seed (Guezotia abyssinica cass). Phytochemical Analysis 14: 366- 370.

Nielsen SS (2002), Introduction to Chemical Analysis of Foods, (CBS Publisher and Distributors, New Delhi, India.) 2002, pp. 257 - 390.

Ogbunugafor HA, Eneh FU, Ozunba AN, Igwo-Ezikpe MN, Okpuzor J, Igwilo IO, Adenekan SO and Onyekwelu OA (2011), Physicochemical and antioxidant properties of Moringa oleifera seed oil. Pak. J. Nutr. 10(5): 409 - 414.

Okoli BE (1984), Wild and cultivated cucurbits in Nigeria. Economic Botany 38(3): 350-357.
Oshodi AA (1992), Proximate composition, nutritionally valuable minerals and function properties of Adenopus breviflorus benth seed flour and protein concentrate. Food Chem. 45(2): 79-87.

Oshodi AA (1996), Amino acid and fatty acid composition of Adenopus breveflorus benth seed. Int. J. Food Sci. Nutr. 47(4): 295-298.

Pearson D (1976), The Chemical Analysis of Foods, $7^{\text {th }}$ Ed. (Churchill Living Stone.) 1976, pp.6 - 14, 200 - 227.

Rauken MD and Kill RC (1993), Fats and fatty acid foods. In: Food Industries Mannual. M.D. Rauken and R.C. Kill (Eds.), 23 ${ }^{\text {rd }}$ Ed. (Longman, London.) 1993, pp.288 - 327.

Reward MH (1997), Fat and Oil, McGraw-Hill, Encyclopedia of Science and Technology ( $8^{\text {th }}$ Ed.). (McGraw-Hill Inc. U.S.A) 1997, pp.17-28.

Salunkhe DK, Chavan RW and Adsule KSS (1992), World Oil Seed, Chemistry Technology and Utilization. (An AVI Book Published by Van Nostrand Reinhold, New York) 1992, pp.148 - 192.

Umerie SC, Onuagha MC and Nwobi SC (2009), Characterization and utilization of Adenopus breviflorus Benth (Cucurbitaceae) Seed oil. Nat. Appl. Sci. J. 10(1): 104-110.

Weihrauch JL and Teter BB (1994), Fruit and vegetable byproducts as sources of oil. In: B.S. Kamel and Y. Kakuda. (Eds.), Technological Advanced in improved and Alternative sources of Lipids, $1^{\text {st }}$ Ed., (Academic and Professional, London) 1994, pp.177 - 208.

Received: 04 January 2016; Revised: 02 February 2016; Accepted: 24 April 2016. 